\title{
New Strategies for Rehabilitation and Pharmacological Treatment of Fatigue Syndrome in Multiple Sclerosis
}

\author{
Ewa Zielińska-Nowak ${ }^{1}\left[\right.$, Lidia Włodarczyk ${ }^{2}$, Joanna Kostka ${ }^{3}\left[\right.$ and Elżbieta Miller ${ }^{1, *(\mathbb{C}}$ \\ 1 Department of Neurological Rehabilitation, Medical University of Lodz, Milionowa 14, 90-001 Lodz, Poland; \\ ewa.zielinska@umed.lodz.pl \\ 2 Department of Occupational Diseases and Environmental Health, Nofer Institute of Occupational Medicine, \\ 91-348 Lodz, Poland; lidia.monika.wlodarczyk@gmail.com \\ 3 Department of Gerontology, Medical University of Lodz, Milionowa 14, 90-001 Lodz, Poland; \\ joanna.kostka@umed.lodz.pl \\ * Correspondence: elzbieta.dorota.miller@umed.lodz.pl; Tel.: +48-(0)426-667-7461; Fax: +48-042-676-1785
}

Received: 27 September 2020; Accepted: 5 November 2020; Published: 7 November 2020

check for updates

\begin{abstract}
Multiple sclerosis (MS) is the most common autoimmune disease of the central nervous system (CNS), with an inflammatory demyelinating basis and a progressive course. The course of the disease is very diverse and unpredictable. Patients face many problems on a daily basis, such as problems with vision; sensory, balance, and gait disturbances; pain; muscle weakness; spasticity; tremor; urinary and fecal disorders; depression; and rapidly growing fatigue, which significantly influences quality of life among MS patients. Excessive fatigue occurs in most MS patients in all stages of this disease and is named MS-related fatigue. The crucial issue is the lack of effective treatment; therefore, this review focuses not only on the most common treatment methods, but also on additional novel therapies such as whole-body cryotherapy (WBC), functional electrical stimulation (FES), and non-invasive brain stimulation (NIBS). We also highlight the advantages and disadvantages of the most popular clinical scales used to measure fatigue. The entire understanding of the origins of MS-related fatigue may lead to the development of more effective strategies that can improve quality of life among MS patients. A literature search was performed using MEDLINE, EMBASE, and PEDro databases.
\end{abstract}

Keywords: multiple sclerosis; fatigue; pharmacological treatment; rehabilitation; physical activity; aerobic training; functional electrical stimulation; non-invasive brain stimulation

\section{Introduction}

Multiple sclerosis (MS) is the most common autoimmune disease of the central nervous system, with an inflammatory demyelinating and progressive course of the disease in humans (usually onset is at 20-40 years of age). The etiology of this disease is still not fully understood [1]. In Europe, the total estimated prevalence rate for MS is 83 per 100,000, with higher rates for women than men [2].

The course of the disease varies considerably depending on the patient, with the differences relating to the rate of the disease development, age of onset, and the number and severity of symptoms. Taking into account the clinical course and the progression of symptoms, four main disease courses have been specified: relapsing-remitting (RRMS), secondary progressive (SPMS), primary progressive (PPMS), and progressive relapsing MS (PRMS).

The clinical picture in MS is very diverse and variable and the symptomatology depends on the localization of damage in the central nervous system. The onset of the disease is usually 
monosymptomatic, and over time it turns into a wide range of coexisting symptoms, such as paralysis, ataxia, spasticity, and fatigue syndrome (FS) [1].

The problem of fatigue affects the vast majority (up to 75\%) of patients with MS and is reported as one of the most burdensome symptoms [3].

The aim of this study is to show the effectiveness of various methods, both pharmacological and non-pharmacological, in the treatment of chronic fatigue in patients with MS. An attempt to present not only standard methods, but also new, modern methods that can support the effectiveness of therapy in this group of patients has been made.

\subsection{Fatigue in Multiple Sclerosis}

Fatigue is defined as an overwhelming feeling of exhaustion and lack of energy. Patients have the impression that the effort that they have to put into performing a given task is disproportionately high, which as a consequence leads to the avoidance of physical activity [4]. Fatigue is a subjective symptom, therefore it can be confused with a feeling of general weakness or depression [4]. Patients should be carefully examined physically and psychologically, so as not to confuse symptoms of FS with depression or other ailments, as these can require separate treatments.

MS patients with heat sensitivity can experience fatigue as a symptom related to heat, which is identified by the occurrence of a conduction block in Ranvier's nodes (Uhthoff's phenomenon) [5]. Factors such as depression, certain medications (opioids, long-term benzodiazepines, sedatives, painkillers, anticonvulsants, muscle relaxants, or pressure-reducing medications), alcohol or nicotine, sleep disturbances, infections, and fever also exacerbate fatigue [6-8]. Moreover, fatigue usually increases in the afternoon and may be aggravated by stress or even slight physical or mental exertion $[9,10]$.

MS-related fatigue differs from physiological fatigue (tiredness) by being more intense, which is not reduced by sleep or rest, and also by lasting a longer time [11]. A higher prevalence of severe fatigue is observed in progressive relapsing MS compared with relapsing-remitting and primary progressive MS [12]. The symptom of fatigue may herald a relapse and may occur even several weeks or months before it, however it may also persist for a long time and not correlate with relapse or remission [4].

MS-related fatigue can be divided into primary fatigue, which is correlated with demyelination and axonal loss in the CNS, and secondary fatigue, which occurs as a result of MS-related complications, such as sleep disorders, reduced activity, and depression [13]. Physical fatigue refers to bodily exhaustion after performing a physically engaging task, whereas cognitive fatigue is associated with mental exhaustion [14].

Despite the fact that many studies have already been performed, it is still not possible to clearly establish the underlying causes of FS. Among many hypotheses, the most common are disorders of the immune system or sequelae from CNS damage. Specific causes include proinflammatory cytokines (increased TNF- $\alpha$ mRNA expression, TNF- $\alpha$ levels, and interferon- $\gamma$ levels), endocrine influences (decrease in DHEA concentration), axonal loss or increased volumes, and patterns of cerebral activation [15].

\subsection{Fatigue Syndrome Diagnosis}

More than 30 questionnaires have already been created to diagnose this syndrome, but due to the high subjectivity it is difficult to indicate one universal scale. The most widely used scales are the fatigue severity scale (FSS), because it is short (nine questions) and examines several aspects of fatigue; the modified fatigue impact scale (MFIS), comprising 21 questions; the fatigue descriptive scale (FDS); and the visual analogue scale for fatigue (VAS-F) [16]. It is common knowledge that self-report questionnaires are influenced by a variety of factors, not only symptoms of MS, but also social, environmental and emotional factors. Consequently, this estimation is completely subjective. Despite these limitations, both scales (FSS and MFIS) are most commonly used in clinical trials, and therefore their outcomes can be easily compared by scientists. 
Tellez et al. compared these two scales in a study on 354 individuals (231 MS patients and 123 healthy controls) and suggested that both scales provide similar measurements, although cognition and psychosocial functions are more thoroughly measured by the MFIS [17]. Objective assessment of the FS is limited to the observation of a patient while performing psychological and motor exercises, due to the fact that fatigue is characterized by a decrease in strength, concentration, and speed of tasks performance over time, with very large differences in the results of these parameters at the beginning of the task and at the end. Another phenomenon is the observation made during the performance of cognitive tasks, characterized by a decrease in the ability to react and the accuracy of task performance over time during the therapy. Moreover, the key problem in fatigue diagnosis is distinguishing fatigue from depression, cognitive impairment, and sleep disorders. Considering MS-related fatigue is a complex problem, we should use a variety of tools to make a proper diagnosis [18-20].

\section{Methods}

The literature search was performed using MEDLINE, EMBASE, and PEDro databases. In total, 57 articles were analyzed, including 46 original research papers and 11 reviews (meta-analyses, systematic reviews, literature reviews). At the beginning we included articles from the last 10 years, however in order to broaden the perspective the search was extended until the year 2000. All articles that were included covered strategies for rehabilitation and pharmacological treatment of MS-related fatigue and were published in English. Search terms included fatigue therapy, multiple sclerosis, pharmacological treatment, exercise, physical activity, and physical agents. We excluded articles published before the year 2000 in languages other than English and articles that did not mention pharmacological treatment or rehabilitation of MS-related fatigue. No restrictions were set for the type of MS, disability level, or severity of fatigue or disease. Two authors independently searched databases for articles on pharmacological agents and two searched for non-pharmacological therapeutic agents that affect fatigue in MS patients.

\section{Pharmacological Treatment of the Fatigue Syndrome}

Treatment of the FS is extremely difficult due to the lack of thorough understanding of its etiology. The first step in fatigue treatment is ruling out depression and factors that may worsen fatigue, such as sleep disturbances, overheating, stimulants, and pain. The necessity to take certain medications should also be reconsidered (such as benzodiazepines, opiates, codeine-containing drugs, myorelaxants, and anti-anxiety and anti-depressant medications). The standard neurological treatment for MS is focused on reducing the frequency of clinical relapses and new lesion formations. Amantadine, paroxetine, modafinil, and 4-aminopyridine, often taken together with antidepressants, are recommended in neurological fatigue treatment routines [21].

4-Aminopyridine (4-AP) is potent inhibitor of voltage-gated potassium channels $(\mathrm{Kv})$. Studies have shown that 4-AP can improve conduction of action potentials in demyelinated nerve fibers, thereby increasing the release of neurotransmitters in synapses and at the neuromuscular junction [22]. Rossini et al. divided patients treated with 4-aminopyridine into two groups, depending on the concentration of the serum, and observed a positive effect on fatigue in individuals with high serum concentrations $(>30 \mathrm{ng} / \mathrm{mL})$ in comparison to the placebo group [23]. Another drug is amantadine, which is an antiviral agent. The mechanism of its action for treating fatigue among MS patients is unclear, but it may be related to antiviral activity, immune-mediated activity, or an amphetamine-like action [24]. In a blinded, randomized, controlled trial, 60 adult patients with relapsing-remitting MS received 1 month of treatment with amantadine (200 mg daily), acetyl-L-carnitine ( $2 \mathrm{~g}$ daily), modafinil (200 mg daily), or placebo. The outcome was measured using the MFIS scale, and after the treatment period there was a significant difference in contrast analysis between patients on amantadine and the placebo group. No changes or only slight changes were found in the group taking modafinil and acetyl-L-carnitine [25]. Möller et al. also do no not support using modafinil as a treatment for fatigue in MS [26]. A similar clarity applies in Stankoff's randomized, placebo-controlled, double-blind 
study with modafinil vs. placebo, where in both placebo-treated and modafinil-treated groups MFIS scores improved but no significant difference was detected between the two groups [27]. Otherwise, in a small study by Lange et al., fatigue measured by FSS improved significantly in the modafinil group and remained better than in the placebo group after 8 weeks of treatment [28]. To compare the efficacy of acetyl-L-carnitine (ALCAR) with that of amantadine, one of the drugs most widely used to treat MS-related fatigue, 36 MS patients presenting fatigue were enrolled in a randomized, double-blind, crossover study [29]. Statistical analysis showed significant effects of ALCAR compared with amantadine for the FSS $(p=0.039)$.

In this report, the last analyzed drug is paroxetine, which is an antidepressant from the selective serotonin reuptake inhibitors (SSRIs) group. Although paroxetine is mainly prescribed for depression, it has also proven to be effective in decreasing fatigue (as measured by the MFIS scale) [30]. According to a meta-analysis prepared by Tsou et al., only paroxetine improved fatigue, but there is a lack of evidence for amantadine, modafinil, and methylphenidate as treatments for FS [31]. In contrast, the meta-analysis performed by Yang at al. indicated that amantadine, not modafinil, was effective in treating MS-related fatigue. They concluded that current data could not answer whether treatment of MS fatigue using aspirin or 4-aminopyridine is beneficial [32].

As seen above, many drugs have already been tested in the treatment of MS fatigue, however the evidence supporting their effectiveness is uncertain. Studies involving small sample sizes have had conflicting results. Therefore, more studies should be performed to create evidence-based and personalized treatment options for patients affected by MS-related fatigue. We are certainly looking forward to the results of a multicenter trial of three commonly used medications for the treatment of MS-related fatigue (amantadine, modafinil, methylphenidate) versus placebo in fatigued subjects with MS [33]. Table 1 summarizes the standard neurological drugs recommended for MS-related fatigue and the main findings from clinical studies (Table 1).

Table 1. Neurological standards for the pharmacological treatment of fatigue.

\begin{tabular}{|c|c|c|c|c|c|}
\hline $\begin{array}{l}\text { Study, Year, } \\
\text { Reference }\end{array}$ & Study Design & $\begin{array}{c}\text { Specific } \\
\text { Treatment }\end{array}$ & $\begin{array}{l}\text { Control } \\
\text { Group }\end{array}$ & $\begin{array}{l}\text { Fatigue } \\
\text { Outcome } \\
\text { Measures }\end{array}$ & Main Findings \\
\hline $\begin{array}{l}\text { Rossini et al., } \\
2001 \text { [23] }\end{array}$ & $\begin{array}{l}\text { Randomized, } \\
\text { controlled trial, } \\
n=54,6 \text { weeks }\end{array}$ & 4-AP & Placebo & FSS & $\begin{array}{l}\text { - Changes in fatigue scores, EDSS, and cognitive } \\
\text { functions were not significantly different } \\
\text { between 4-AP and placebo. } \\
\text { - When patients treated with 4-AP were divided } \\
\text { into two groups according to the serum level of } \\
\text { 4-AP, a significant effect on fatigue compared } \\
\text { with placebo was observed in the "high level" } \\
(>30 \mathrm{ng} / \mathrm{mL}) \text { group }(p=0.05) \text {. }\end{array}$ \\
\hline $\begin{array}{l}\text { Ledinek et al., } \\
2013 \text { [25] }\end{array}$ & $\begin{array}{l}\text { Randomized, } \\
\text { controlled trial, } \\
n=60,1 \text { month }\end{array}$ & $\begin{array}{l}\text { Amantadine, } \\
\text { modafinil, } \\
\text { and ALCAR }\end{array}$ & Placebo & MFIS & $\begin{array}{l}\text { - Significantly lower mean MFIS score after one } \\
\text { month in patients on amantadine compared to } \\
\text { placebo (mean difference }=17.3, p=0.001 \text { ). } \\
\text { There was also a trend of lower MFIS scores in } \\
\text { ALCAR group in comparison to placebo (mean } \\
\text { difference }=12.4, p=0.05 \text {, with } \\
\text { Keppel-corrected alpha of } 0.046) .\end{array}$ \\
\hline $\begin{array}{l}\text { Möller et al., } \\
2011 \text { [26] }\end{array}$ & $\begin{array}{l}\text { Randomized, } \\
\text { controlled trial, } \\
n=121,8 \text { weeks }\end{array}$ & Modafinil & Placebo & FSS, MFIS & $\begin{array}{l}\text { - Both treatment groups showed improvements } \\
\text { over time. While mean FSS at } 8 \text { weeks showed } \\
\text { a trend difference between groups in the } \\
\text { intention-to-treat analysis, the primary } \\
\text { endpoint was not met. } \\
\text { - Assessment of cognitive impairment by SDMT } \\
\text { and PASAT showed contradictory results. } \\
\text { - All other secondary endpoints were not met. }\end{array}$ \\
\hline
\end{tabular}


Table 1. Cont.

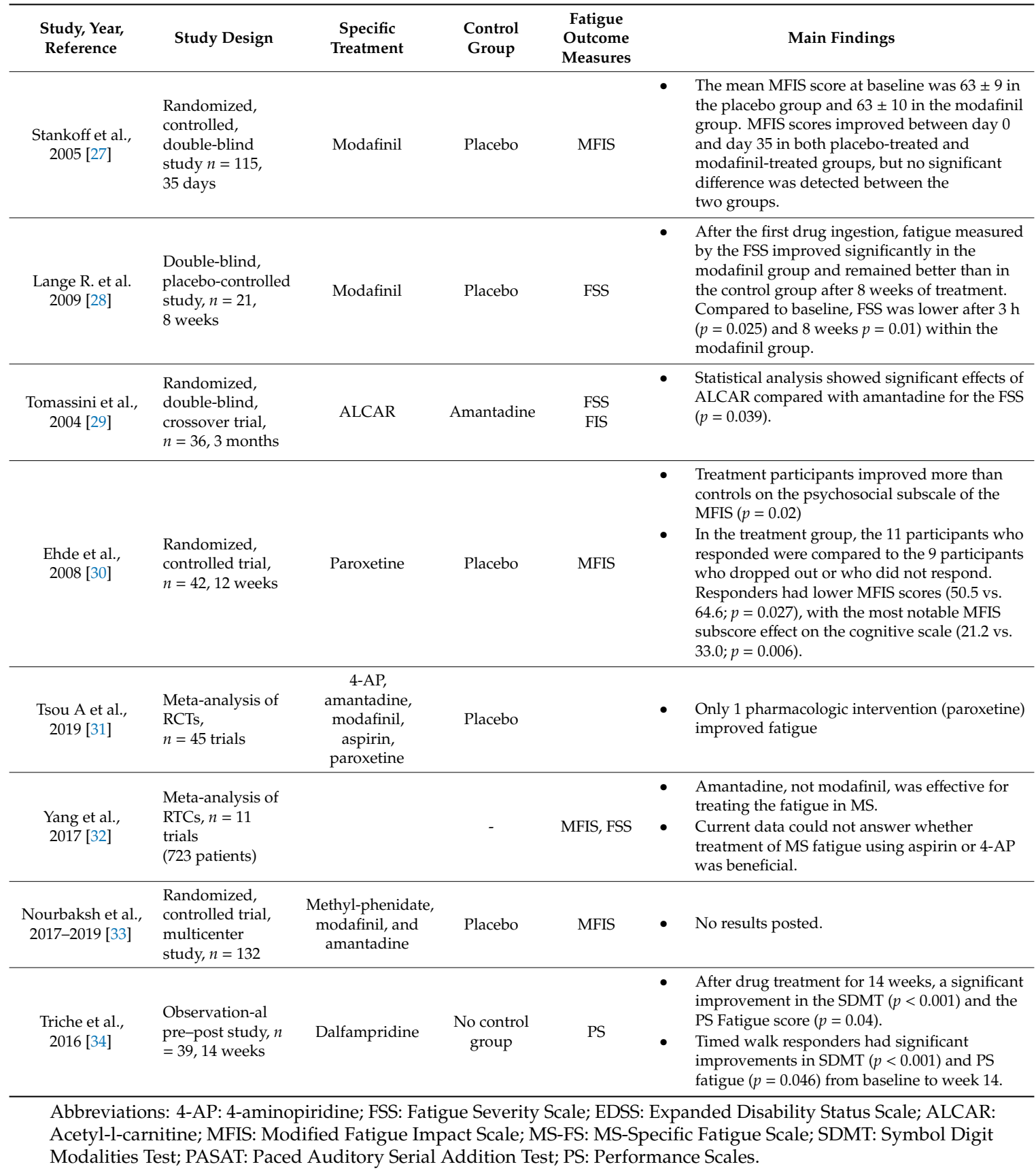

\section{Non-Pharmacological Treatment of Fatigue Syndrome}

MS is long-lasting disease with clinical progression of irreversible symptoms, for which conventional therapy is often not effective. It seems that new therapies should be more targeted to one particular symptom. In 2014, the American Academy of Neurology published a comprehensive literature review and evidence-based practice guidelines for complementary and alternative medical therapies (CAM) for MS [35]. Several oral therapies, such as cannabis, ginkgo biloba, magnetic field therapy, and reflexology, were shown to be potentially effective for treating MS-related fatigue, disability, and for improving quality of life. 


\subsection{Physical Rehabilitation}

The least invasive method of treatment is physiotherapy. In one study, it has been shown that the implementation of an appropriate training plan largely based on aerobic exercise reduces fatigue by about $40-50 \%$, however the exercise program should be individually adjusted, taking into account all possible symptoms of patients with MS and co-existing diseases [36]. Rehabilitation of patients with MS is a particularly demanding task due to the wide spectrum of symptoms and the inability to predict the course of the disease.

According to the meta-analysis of different types of fatigue management in MS patients, interventions based on rehabilitation may have even stronger and more significant effects on reducing fatigue than medication [37].

\subsubsection{Physical Activity and Exercise Therapy}

Current studies support the statement that training programs in MS cause positive effects, especially for those with mild and moderate disability levels. There is some evidence that physically active MS persons are characterized by better results in fatigue scales than non-exercisers [38]. According to the Cochrane review based on 36 studies involving 1603 people with MS, exercise interventions (particularly endurance, mixed, or "other" training) are safe and may be effective in reducing fatigue symptoms. However, the authors note that in the future, high-quality research is needed to confirm the effectiveness of exercise therapy [39].

There are some potential mechanisms that may explain the beneficial effects of physical activity and exercise on both primary and secondary fatigue in people with MS. In the case of primary fatigue, attention is paid to changes in the CNS under the influence of regular exercise (decreased neurodegeneration, improved synaptic plasticity and neurogenesis through increased BDNF level), immunologic changes (reduction of inflammation), and neuroendocrine changes (through normalization of hypothalamic-pituitary-adrenal axis dysfunction). Many of the above-mentioned effects of exercise (especially aerobic training) can also positively influence secondary fatigue. It is known that regular physical activity induces benefits, such as improvements in quality of sleep and mood, reduction of depression symptoms, and improvement of aerobic capacity caused by positive changes in cardiovascular and locomotor systems. These improvements positively influence motor functions and reduce energy expenditure during everyday activities [40].

Despite the evidence of the safety and beneficial effects (including fatigue reduction) of physical activity in MS, people with MS are less active than the healthy controls [41]. Meanwhile, deconditioning related to inactivity has many negative consequences, including deterioration of functional fitness and intensification of fatigue symptoms. Due to the wide range of symptoms and the severity of the disease, recent recommendations for physical activity for MS patients include different exercise strategies and physical activity recommendations, depending on the degree of disability (based on expanded disability status scale (EDSS) ranges) [42]. These recommendations include many different forms of physical activity and exercise that may be performed by MS patients, such as aerobic activity (e.g., cycle ergometry, treadmill or overground walking, rowing, jogging, aquatic activities), resistance training, flexibility exercises, neuromotor training (including pilates, dance, yoga, tai chi, hippotherapy, exercise with virtual reality), and breathing exercises. The intensity of the activity, the form of exercise, and the training volume, as mentioned above, depend on the severity of the disease. However, even the most vulnerable patients (EDSS 9.0-inability to perform most activities of daily living) should be as active as possible. On the other hand, even intense exercise such as running or cycling is allowed in people with SM with mild impairment.

Most often moderate exercise intensity is recommended for MS individuals, however single studies show that high-intensity resistance training [43] and high-intensity aerobic training [44] are safe and may lead to even better improvements in many aspects of functioning, including measures of fatigue in MS individuals. Actually, there are some studies that have presented reductions of fatigue in FSS or MFIS scales after applying aerobic exercise programs [45-47]. 
Although physical activity is recommended in MS, it is known that exercise increases the metabolic rate, which is connected with heat generation and an increase of body temperature, which may not be suitable for heat-sensitive patients with MS. Such patients may benefit from training in a cooled room. Devasahayam et al. studied a vigorous aerobic walking program conducted in a room cooled to $16{ }^{\circ} \mathrm{C}$ using a bodyweight-supported treadmill (BWST) for people with moderate to severe MS-related disability, which resulted in a reduction of the fatigue symptom [48].

Some studies indicate a positive influence of aquatic exercises on MS-related fatigue [49-51]. This method also provides the relief and ideal resistance for light strengthening exercises. The additional benefit of exercising in water is a sense of security in case of losing balance and the risk of falling. Additionally, thanks to the aquatic environment being at the right temperature, the effect of muscle relaxation appears. It was also proven that patients who practiced yoga under the supervision of a qualified instructor had lower MFIS scores after 8 weeks of three yoga sessions per week [52].

Music therapy may also be an interesting way of diversifying the training. This therapy stimulates patients to move and allows them to keep their mind off of the disease for a while, forgetting about the pain and limitations and simply performing movements to the rhythm of music. Dance training may have positive effects on fatigue, cognitive performance during a task, and motor functions [53].

Fatigue in MS is associated with functional performance. In the study by Garg et al., MS participants with higher levels of fatigue were characterized by greater impairment of both performance-based and self-reported functional mobility [54]. Taking this into account, the rehabilitation program for this group of patients should be focused on functional deficits. In this area Bobath, Frenkel exercises or Proprioceptive Neuromuscular Facilitation (PNF) approaches are often used for patients with MS [55]. Table 2 presents research articles on different types of physical activity performed by patients with MS-related fatigue (Table 2).

Table 2. Different types of physical activity performed by multiple sclerosis (MS) patients with fatigue.

\begin{tabular}{|c|c|c|c|c|}
\hline $\begin{array}{c}\text { Study, Year, PEDro } \\
\text { Score, Reference }\end{array}$ & Study Design & Type of Intervention & $\begin{array}{l}\text { Outcome } \\
\text { Measures }\end{array}$ & Main Findings \\
\hline $\begin{array}{l}\text { Hasanpour et al., } \\
2016 \\
\text { PEDro: } 5 / 10 \text { [45] }\end{array}$ & $\begin{array}{l}\text { Randomized, } \\
\text { controlled trial; } \\
n=90\end{array}$ & $\begin{array}{l}\text { Yoga, aerobics exercises: } \\
12 \text { weeks, } 3 \text { sessions per } \\
\text { week, } 40 \text { min per session }\end{array}$ & $\begin{array}{l}\text { Rotten fatigue } \\
\text { test, SF-36 }\end{array}$ & $\begin{array}{l}\text { - Fatigue decreased in yoga and exercise groups, } \\
\text { but in the control group, the fatigue } \\
\text { severity increased. } \\
\text { Physical function, physical and emotional role, } \\
\text { social function, energy, mental status and } \\
\text { overall hygiene increased; pain and fatigue } \\
\text { were relieved among patients. }\end{array}$ \\
\hline $\begin{array}{l}\text { Mokhtarzade et al., } \\
2017 \\
\text { PEDro: 5/10 [46] }\end{array}$ & $\begin{array}{l}\text { Randomized, } \\
\text { controlled trial; } \\
n=40\end{array}$ & $\begin{array}{l}\text { Aerobic exercise: } \\
8 \text { weeks, } 3 \text { days per } \\
\text { week, upper and lower } \\
\text { limb aerobic interval } \\
\text { training program }\end{array}$ & FSS, MSQOL-54 & $\begin{array}{l}\text { - Significant decrease in fatigue after the 8-week } \\
\text { aerobic interval training }(p<0.05) \text {. } \\
\text { A considerable change in MSQOL-54 (total) } \\
\text { and physical and mental quality of life } \\
\text { subsequent to the exercise training }(p<0.05) \text {. }\end{array}$ \\
\hline $\begin{array}{l}\text { Mostert S, et al., } \\
2002 \\
\text { PEDro: } 3 / 10 \text { [47] }\end{array}$ & $\begin{array}{l}\text { Clinical trial; } \\
n=26\end{array}$ & $\begin{array}{l}\text { Aerobics exercise: } \\
4 \text { weeks, } 5 \text { sessions a } \\
\text { week, } 30 \text { min per session, } \\
\text { bicycle exercise with } \\
\text { individualized intensity }\end{array}$ & FSS, SF-36 & $\begin{array}{l}\text { A significant rightward placement of the } \\
\text { aerobic threshold (VO2 }+13 \% \text {; work rate }+ \\
11 \%) \text {, an improvement of health perception } \\
\text { (vitality }+46 \% \text {; social interaction }+36 \%) \text {, } \\
\text { an increase of activity level }(+17 \%) \text { and a } \\
\text { tendency to lower fatigue in the MS } \\
\text { training group. } \\
\text { The level of excessive fatigue measured by FSS } \\
\text { was } 60-67 \% \text { higher in MS groups in comparison } \\
\text { to matched controls. }\end{array}$ \\
\hline $\begin{array}{l}\text { Devasahayam } \\
\text { et al., } 2020 \\
\text { PEDro: none [48] }\end{array}$ & $\begin{array}{l}\text { Clinical trial; } \\
n=10\end{array}$ & $\begin{array}{l}\text { Aerobic walking training } \\
\text { in a room cooled to } 16^{\circ} \mathrm{C} \\
\text { using bodyweight- } \\
\text { supported treadmill }\end{array}$ & FSS, MFIS, SF-36 & $\begin{array}{l}\text { - } \quad \text { Fatigue in MFIS significantly improved. } \\
\text { - } \quad \text { The effect was sustained after } 3 \text { months. }\end{array}$ \\
\hline
\end{tabular}


Table 2. Cont.

\begin{tabular}{|c|c|c|c|c|}
\hline $\begin{array}{l}\text { Study, Year, PEDro } \\
\text { Score, Reference }\end{array}$ & Study Design & Type of Intervention & $\begin{array}{l}\text { Outcome } \\
\text { Measures }\end{array}$ & Main Findings \\
\hline $\begin{array}{l}\text { Kargarfard et al., } \\
2017 \\
\text { PEDro: } 7 / 10 \text { [49] }\end{array}$ & $\begin{array}{l}\text { Randomized, } \\
\text { controlled trial; } \\
n=34\end{array}$ & $\begin{array}{l}\text { Aquatic exercise: } 8 \\
\text { weeks, } 3 \text { sessions per } \\
\text { week, sessions } 45-60 \\
\text { min, water temperature: } \\
28-30^{\circ} \mathrm{C}\end{array}$ & MFIS & $\begin{array}{l}\text { - Aquatic exercise training improved functional } \\
\text { capacity, balance, and perceptions of fatigue in } \\
\text { women with MS. } \\
\text { All outcome measures improved in the } \\
\text { experimental group: MFIS (pretest mean } \pm \text { SD, } \\
43.1 \pm 14.6 \text {; post-test mean } \pm \text { SD, } 32.8 \pm 5.9 \text {; } \\
p<0.01 \text { ). }\end{array}$ \\
\hline $\begin{array}{l}\text { Kooshiar et al., } \\
2015 \\
\text { PEDro: } 4 / 10[50]\end{array}$ & $\begin{array}{l}\text { Randomized, } \\
\text { controlled trial; } \\
n=37\end{array}$ & $\begin{array}{l}\text { Aquatic therapy: } \\
8 \text { weeks, } 3 \text { sessions per } \\
\text { week and } 45 \text { min per } \\
\text { session, water } \\
\text { temperature: } 28-29.5^{\circ} \mathrm{C}\end{array}$ & $\begin{array}{l}\text { FSS, MFIS, } \\
\text { MQLIM }\end{array}$ & $\begin{array}{l}\text { - Significant effects of aquatic exercise on } \\
\text { physical and psychosocial fatigue perception, } \\
\text { QoL, and fatigue severity }(p=0.001) \text {. } \\
\text { - Non-significant effect for cognitive fatigue } \\
\text { perception }(p>0.05) \text {. }\end{array}$ \\
\hline $\begin{array}{l}\text { Razazian, et al., } \\
2016 \\
\text { PEDro: } 6 / 10[51]\end{array}$ & $\begin{array}{l}\text { Randomized, } \\
\text { controlled trial; } \\
n=54\end{array}$ & $\begin{array}{l}\text { Aquatic exercise: } \\
8 \text { weeks, } 3 \text { sessions per } \\
\text { week and } 1 \mathrm{~h} \text { per session, } \\
\text { water temperature: } \\
28-30^{\circ} \mathrm{C} \\
\text { Yoga: } 8 \text { weeks, three } \\
\text { times per week, about } \\
60 \text { min }\end{array}$ & $\begin{array}{l}\text { FSS, } \\
\text { Beck Depression } \\
\text { Inventory, } \\
\text { 10-point visual } \\
\text { analogue scale } \\
\text { for paresthesia }\end{array}$ & $\begin{array}{l}\text { A significant decrease in the yoga and aquatic } \\
\text { exercise groups compared with the } \\
\text { non-exercise control condition and fatigue, } \\
\text { depression, and paresthesia over time. }\end{array}$ \\
\hline $\begin{array}{l}\text { Garrett et al., } 2013 \\
\text { PEDro: 6/10 [52] }\end{array}$ & $\begin{array}{l}\text { Randomized, } \\
\text { controlled trial }\end{array}$ & $\begin{array}{l}\text { Physiotherapist } \\
\text { (PT)-led exercise } \\
(n=80), \\
\text { yoga }(n=77), \\
\text { fitness instructor } \\
\text { (FI)-led exercise }(n=86)\end{array}$ & MFIS, MSIS & $\begin{array}{l}\text { - Statistically significant improvement in the } \\
\text { MSIS-29 psychological component and both the } \\
\text { MFIS total and physical subscales, which were } \\
\text { greater than the control }(p<0.05) \text {. }\end{array}$ \\
\hline $\begin{array}{l}\text { Tarakci et al., } 2013 \\
\text { PEDro: } 8 / 10 \text { [56] }\end{array}$ & $\begin{array}{l}\text { Randomized, } \\
\text { controlled trial; } \\
n=99\end{array}$ & $\begin{array}{l}\text { Group exercise led by } \\
\text { physical therapist }\end{array}$ & FSS & $\begin{array}{l}\text { - Statistically significant improvements for all } \\
\text { outcome measures in the exercise group }(n=51) \\
(p<0.01) \text {. } \\
\text { In the control group }(n=48) \text {, there was a } \\
\text { statistically significant increment only in the } \\
\text { FSS score }(p=0.002) \text {. }\end{array}$ \\
\hline $\begin{array}{l}\text { Sangelaji et al., } \\
2014 \\
\text { PEDro: } 3 / 10 \text { [57] }\end{array}$ & $\begin{array}{l}\text { Randomized, } \\
\text { controlled trial; } \\
n=59\end{array}$ & $\begin{array}{l}\text { Combination exercises: } \\
10 \text { weeks, } 3 \text { sessions a } \\
\text { week, } 20-40 \text { min } \\
\text { per session, } \\
\text { stretching and aerobic } \\
\text { exercises, strengthening } \\
\text { exercises with and } \\
\text { balancing exercises. }\end{array}$ & $\begin{array}{l}\text { FSS, } \\
\text { 6-min Walk } \\
\text { Test, EDSS } \\
\text { quality of } \\
\text { life tests }\end{array}$ & $\begin{array}{l}\text { Significant changes in the intervention group in } \\
\text { comparison to the control group in the second } \\
\text { phase of the study compared to the first one for } \\
\text { all tests except EDSS, } p=0.60 \text { (EDSS mean } \\
\text { values at the beginning: intervention group: } \\
\text { 1.7; control group 1.96; at the end: intervention } \\
\text { group: } 2.2 \text {; control group: } 2.74) ; \text { FSS: }-6.9 \text {, } \\
p=0.02 \text {, Mental Quality of Life: } 16.36, p=0.001 \text {; } \\
\text { Physical QOL: } 12.17, p=0.001 \text {, six minute } \\
\text { walking: } 137.2, p<0.0001 \text {; Berg: } 3.34 \\
p<0.0001 \text {. }\end{array}$ \\
\hline $\begin{array}{l}\text { McCullagh et al., } \\
2008 \\
\text { PEDro: } 4 / 10 \text { [58] }\end{array}$ & $\begin{array}{l}\text { Randomized, } \\
\text { controlled trial; } \\
n=30\end{array}$ & $\begin{array}{l}\text { Exercise: } 3 \text { months, } \\
2 \text { sessions per week, } \\
\text { participants also } \\
\text { exercised independently } \\
\text { once a week. }\end{array}$ & $\begin{array}{l}\text { MFIS, MSIS-29, } \\
\text { FAMS }\end{array}$ & $\begin{array}{l}\text { Exercise group had significantly greater } \\
\text { improvements in exercise capacity and fatigue } \\
\text { (MFIS: }-13 \text { in exercise group versus } 1 \text { in control } \\
\text { group, } p=0.02 \text { ). } \\
\text { Improvements in QOL and fatigue lasting } \\
\text { beyond the program. }\end{array}$ \\
\hline
\end{tabular}

Abbreviations: PEDro: Physiotherapy Evidence Database; FSS: Fatigue Severity Scale; MFIS: Modified Fatigue Impact Scale; MQLIM: Multicultural Quality of Life Index; QoL: quality of life; MSIS: Multiple Sclerosis Impact Scale; MSQOL-54: Multiple Sclerosis Quality of Life Questionnaire; SF-36: 36-Item Short Form Health Survey; MSIS-29:

Multiple Sclerosis Impact Scale-29; FAMS: Functional Assessment of Multiple Sclerosis.

\subsubsection{Physical Agents}

In order to strengthen the effects of physical rehabilitation, it is worth using therapies involving physical agents. Due to the negative influence of high temperature on nerve conduction and fatigue in MS patients, any procedures involving significant increases of body temperature are not recommended.

As has been previously reported in the literature, treatments with cold agents are widely used in this group of patients. For instance, applying local cryotherapy to the shoulder area reduces intention or systemic tremor, which has a beneficial effect on the patient's functional state [59]. Single studies indicate that treatment with cold may have positive effects for both the body and the psyche, and that the improvement in well-being can be particularly observed in people suffering from depression [60]. It is worth paying attention to the possibility of using whole-body cryostimulation (WBC) to reduce fatigue. In the study by Miller et al., after ten sessions of WBC (one exposure 
per day at $-110{ }^{\circ} \mathrm{C}$ or lower), patients reported improvements in functional status and feeling of fatigue [61]. Lowering the body temperature with a cooling garment also seems to have a similar positive influence on fatigue $[62,63]$. Even a single session with a Rehband cooling garment caused many positive changes for MS patients, including subjective improvements in fatigue [64]. The authors of the above-mentioned articles did not report any side effects for the applied treatments [61-64]. Patients were excluded from the whole-body cryotherapy study if they had any of the following contraindications: antihypertensive or vasoactive medications or diuretics within the previous month; or any other significant medical diagnoses, including thyroid, hypothalamic or cardiovascular disease, circulatory or breathing insufficiency, clotting, embolisms, inflammation of blood vessels, open wounds, ulcers, serious cognitive disturbances, fever, addictions, claustrophobia, or over-sensitivity to cold [61]. Table 3 presents clinical studies on cold therapies in patients with MS-related fatigue.

Table 3. Clinical studies of cold therapies in patients with MS-related fatigue.

\begin{tabular}{|c|c|c|c|c|}
\hline $\begin{array}{c}\text { Study, Year, PEDro } \\
\text { Score, Reference }\end{array}$ & Study Design & $\begin{array}{c}\text { Potential } \\
\text { Intervention }\end{array}$ & $\begin{array}{c}\text { Outcome } \\
\text { Measures }\end{array}$ & Main Findings \\
\hline $\begin{array}{l}\text { Miller et al., } 2016 \\
\text { PEDro: none [61] }\end{array}$ & $\begin{array}{l}\text { Case-control } \\
\text { study; } n=24\end{array}$ & $\begin{array}{l}10 \times 3 \mathrm{~min} \\
\text { WBC sessions (one } \\
\text { exposure per day at } \\
-110^{\circ} \mathrm{C} \text { or lower) }\end{array}$ & $\begin{array}{l}\text { FSS, RMA, } \\
\text { MSIS-29, EDSS }\end{array}$ & $\begin{array}{l}\text { - Improvement in the functional status and } \\
\text { in the feeling of fatigue. } \\
\text { - High fatigue group achieved better results } \\
\text { than low fatigue, especially in the } \\
\text { MSIS-29-PHYS, MSIS-29-PSYCH, RMA1, } \\
\text { and RMA3. } \\
\text { Outcomes in the EDSS, RMA2, and FSS } \\
\text { were similar in both groups. } \\
\text { Mean EDSS in low fatigue group before } \\
\text { treatment: } 5.1 \pm 0.7 \text {, after: } 4.8 \pm 0.7 \text {; } \\
\text { Mean EDSS in high fatigue group before } \\
\text { treatment: } 5.2 \pm 1.1 \text {, after: } 5.0 \pm 1.1\end{array}$ \\
\hline $\begin{array}{l}\text { Özkan et al., } 2017 \\
\text { PEDro: none [63] }\end{array}$ & $\begin{array}{l}\text { Case-control } \\
\text { study; } n=75\end{array}$ & $\begin{array}{l}\text { Colling suit (vest) } \\
\text { applied once a day } \\
\text { for } 40 \mathrm{~min}, 4 \text { weeks }\end{array}$ & $\begin{array}{l}\text { FIS, FSS, and } \\
\text { Modified Barthel } \\
\text { Index. }\end{array}$ & $\begin{array}{l}\text { - Improvements from baseline in all } \\
\text { measures of fatigue } \\
\text { At the 4th-week measurement, } \\
\text { the experimental group scored } \\
\text { significantly better on the Modified } \\
\text { Barthel Index }\end{array}$ \\
\hline $\begin{array}{l}\text { Nilsagård et al., } \\
2006 \\
\text { PEDro: } 7 / 10 \text { [64] }\end{array}$ & $\begin{array}{l}\text { Randomized, } \\
\text { controlled } \\
\text { crossover study; } \\
n=43\end{array}$ & $\begin{array}{l}\text { Single session } \\
\text { with Rehband } \\
\text { cooling garment }\end{array}$ & $\begin{array}{l}\text { A study-specific } \\
\text { questionnaire to } \\
\text { evaluate subjective } \\
\text { experiences. } \\
\text { 10TW, 30TW, TUG, } \\
\text { oral temperature, } \\
\text { spasticity, standing } \\
\text { balance }\end{array}$ & $\begin{array}{l}\text { Improvement in 10TW, 30TW, one-legged } \\
\text { stance, tandem stance (right) and TUG. } \\
\text { Improvements in fatigue, spasticity, } \\
\text { weakness, balance, gait, transfers, } \\
\text { ability to think clearly and time to recover. }\end{array}$ \\
\hline
\end{tabular}

Abbreviations: PEDro: Physiotherapy Evidence Database; WBC: Whole-body cryostiumlation; FSS: Fatigue Severity Scale; EDSS: Expanded Disability Status Scale; RMA: Rivermead Motor Assessment; MSIS-29: Multiple Sclerosis Impact Scale; SEP-59: French version of the Multiple Sclerosis Quality Of Life; FIS: Fatigue Impact Scale; 10TW: 10-metre timed walk; 30TW: 30-metre timed walk; TUG: timed "up and go".

The influence of pulsed magnetic field therapy (PMFT) has also been evaluated among this group of patients and it seems that it might be helpful in alleviating fatigue. In the study performed by Lappin et al., a daily exposure to a small, portable pulsing electromagnetic field generator caused improvements in fatigue and overall quality of life [65]. The significant difference in MFIS outcomes was also noted after 12 weeks of using BEMER magnetic field treatment for $8 \mathrm{~min}$, twice daily [66]. Although some studies indicate slight positive impacts of PMFT on fatigue, their outcomes were not statistically significant $[67,68]$. The authors of the above-mentioned articles did not report any side effects for the applied therapies. The most common exclusion criteria were exacerbation of MS, pregnancy, pacemaker, serious or chronic diseases, psychiatric disorders, and epilepsy [65-68]. Table 4 presents the influence of magnetic field therapy on MS-related fatigue (Table 4). 
Table 4. Clinical studies of magnetic field therapy in patients with MS-related fatigue.

\begin{tabular}{|c|c|c|c|c|}
\hline $\begin{array}{l}\text { Study, Year, PEDro } \\
\text { Score, Reference }\end{array}$ & Study Design & Potential Intervention & $\begin{array}{l}\text { Outcome } \\
\text { Measures }\end{array}$ & Main Findings \\
\hline $\begin{array}{l}\text { Lappin et al., } 2003 \\
\text { PEDro: } 7 / 10 \text { [65] }\end{array}$ & $\begin{array}{l}\text { Multi-site, } \\
\text { double-blind, } \\
\text { placebo-controlled, } \\
\text { crossover trial; } \\
n=117\end{array}$ & $\begin{array}{l}\text { Daily exposure to a small, } \\
\text { portable PMFT generator }\end{array}$ & MSQLI & $\begin{array}{l}\text { - Improvements in fatigue and overall } \\
\text { quality of life were significantly greater in } \\
\text { the active device group. }\end{array}$ \\
\hline $\begin{array}{l}\text { Piatkowski et al., } \\
2009 \\
\text { PEDro: } 7 / 10 \text { [66] }\end{array}$ & $\begin{array}{l}\text { Randomized, } \\
\text { double-blind, } \\
\text { controlled trial; } \\
n=37\end{array}$ & $\begin{array}{l}\text { BEMER magnetic field } \\
\text { treatment for } 8 \text { min twice } \\
\text { daily in comparison to } \\
\text { placebo for } 12 \text { weeks }\end{array}$ & MFIS, FSS & $\begin{array}{l}\text { - A significant difference of MFIS value } \\
\text { after } 12 \text { weeks in favor of the verum } \\
\text { group ( } 26.84 \text { versus } 36.67 ; \mathrm{p} 1 / 40.024 \text { ). } \\
\text { FSS values were significantly lower in the } \\
\text { verum group after } 12 \text { weeks (3.5 versus } \\
\text { 4.7; p } 1 / 40.016 \text { ). } \\
\text { After } 6 \text { weeks follow-up, the groups did } \\
\text { not differ in fatigue (MFIS, FSS). } \\
\text { MFIS: a significant decrease in physical } \\
\text { (p1/40.018) and cognitive (p1/40.041), } \\
\text { but not in psychologic subscales; only in } \\
\text { the verum group regarding the baseline } \\
\text { and } 12 \text { week timepoints. }\end{array}$ \\
\hline $\begin{array}{l}\text { De Carvalho et al., } \\
2012 \\
\text { PEDro: } 6 / 10 \text { [67] }\end{array}$ & $\begin{array}{l}\text { Randomized, } \\
\text { double-blind, } \\
\text { crossover trial; } \\
n=50\end{array}$ & $\begin{array}{l}\text { Systemic pulsed } \\
\text { low-frequency magnetic } \\
\text { field with an intensity of } \\
37.5 \mathrm{mT} \text { and with a } \\
\text { sequence of pulses at } \\
4-7 \mathrm{~Hz} \text {. Total of } 24 \\
\text { sessions, three times a } \\
\text { week for } 8 \text { weeks, } 24 \text { min } \\
\text { per session }\end{array}$ & $\begin{array}{l}\text { FSS, } \\
\text { MFIS, }\end{array}$ & $\begin{array}{l}\text { Improvement in MFIS Physical Score for } \\
\text { T0 (beginning of treatment) }-\mathrm{T} 1 \text { (end of } \\
\text { treatment) }(p<0.05) \text { for time but not for } \\
\text { treatment and time } \times \text { treatment factors. }\end{array}$ \\
\hline $\begin{array}{l}\text { Mostert et al., } 2005 \\
\text { PEDro: 6/10 [68] }\end{array}$ & $\begin{array}{l}\text { Randomized, } \\
\text { controlled trial; } \\
n=25\end{array}$ & $\begin{array}{l}\text { PMFT, single treatment } \\
\text { lasted } 16 \text { min twice daily } \\
\text { over } 3-4 \text { weeks }\end{array}$ & $\begin{array}{l}\text { FSS, } \\
\text { VAS }\end{array}$ & $\begin{array}{l}\text { Over time of rehabilitation, fatigue was } \\
\text { reduced by } 18 \% \text { in TG and } 7 \% \text { in CG, } \\
\text { which was not statistically significant. } \\
\text { A statistically significant immediate effect } \\
\text { of the single treatment session with } 18 \% \\
\text { reduction of fatigue (in VAS) in treatment } \\
\text { group versus } 11 \% \text { in control group }\end{array}$ \\
\hline
\end{tabular}

\begin{abstract}
Abbreviations: PEDro: Physiotherapy Evidence Database; FSS: Fatigue Severity Scale; MFIS: Modified Fatigue Impact Scale; EDSS: Expanded Disability Status Scale; BDE: Beck Depression Inventory; FAMS: Functional Assessment of Multiple Sclerosis; PMFT: Pulsed Magnetic Field Therapy; MSQLI: Multiple Sclerosis Quality of Life Inventory; VAS: Visual Analog Scale.
\end{abstract}

Functional electrical stimulation (FES) is the next physical agent that is being investigated as a potential treatment of fatigue in MS patients [69-71].

In the study by Chang et al., 8 weeks of quadriceps muscle surface FES training for individuals with MS led to significantly reduced fatigue. In addition, a very interesting application of FES is FES connected with cycling [70]. During training, the electrodes are placed on the muscles and electrostimulation supports the movements of the muscles that are engaged during cycling. After 24 weeks of FES cycling training, the authors pointed out the benefits of FES cycling exercise on symptoms of fatigue, cognition, and pain [71]. Nevertheless, it should be noted that these studies were conducted in small groups of patients, hence future research should further develop and confirm these initial findings. In the presented articles, the following contraindications to FES have been mentioned: skin lesions; cancerous cells at the site of electrode placement; the presence of a demand-type pacemaker, defibrillator, or any electrical or metallic implant [69]; history of osteoporosis; other musculoskeletal disorders [70]; epilepsy; unstable fractures; pregnancy [71]. No side effects have been reported. Table 5 highlights the potential value of FES in the treatment of MS-related fatigue (Table 5). 


\subsection{New Therapies: Non-Invasive Brain Stimulation}

Non-invasive brain stimulation (NIBS) is a novel neuromodulatory method that has shown promising treatment effects on several neurological disorders, such as sequelae of stroke and chronic pain. The evaluation of NIBS treatments, such as transcranial direct current stimulation (tDCS), transcranial magnetic stimulation (TMS), transcranial random noise stimulation (tRNS), transcranial alternating current stimulation (tACS), cranial electrotherapy stimulation (CES), and reduced impedance non-invasive cortical electrostimulation (RINCE), has shown that tDCS is a safe and effective method of treating MS-related fatigue. The reduction of fatigue in the analyzed study was statistically significant both after the last stimulation and also after a long period compared to sham stimulation. There were no significant changes observed for TMS and tRNS [72]. A recent study by Chalah et al. showed that bifrontal tDCS seems to modulate fatigue in patients with MS. Eleven fatigued MS patients randomly received two blocks (active and sham $\mathrm{tDCS}$ ) of five consecutive daily sessions of bifrontal tDCS (anode and cathode over the left and right prefrontal cortices, respectively) in a crossover manner, separated by a 3-week washout interval. Active but not sham tDCS resulted in a significant improvement of fatigue at day $5(p<0.05)$, an effect that seems to last at least 1 week following the stimulation $(p=0.05)$ [73]. Similar results were observed by Canchelli et al. [74]. They have recruited ten patients with MS-related fatigue, who received 5-day transcranial direct current stimulation (tDCS) in a randomized, double-blind, sham-controlled, crossover study, with MFIS score reduction at the end of the treatment as the primary outcome. Likewise, in a study performed by Tecchio et al., similar results were obtained-anodal tDCS over bilateral somatosensory areas was able to reduce fatigue in mildly disabled MS patients [75].

Table 5. Clinical studies of FES in patients with MS-related fatigue.

\begin{tabular}{|c|c|c|c|c|}
\hline $\begin{array}{l}\text { Study, Year, } \\
\text { References }\end{array}$ & Study Design & $\begin{array}{c}\text { Potential } \\
\text { Intervention }\end{array}$ & Outcome Measures & Main Findings \\
\hline $\begin{array}{l}\text { Chang et al., } \\
2011 \text { [70] }\end{array}$ & $n=9$ & $\begin{array}{l}8 \text { weeks of } \\
\text { quadriceps muscle } \\
\text { surface FES training }\end{array}$ & $\begin{array}{l}\text { Maximal voluntary } \\
\text { contraction, voluntary } \\
\text { activation level, twitch } \\
\text { force, FI, CFI, Peripheral } \\
\text { Fatigue Index, and MFIS }\end{array}$ & $\begin{array}{l}\text { FI }(p=0.01), \text { CFI }(p=0.02), \\
\text { and MFIS }(p=0.02) \text { scores } \\
\text { improved significantly } \\
\text { Improvements in central } \\
\text { fatigue contributed } \\
\text { significantly to } \\
\text { improvements in general } \\
\text { fatigue }(p<0.01) .\end{array}$ \\
\hline $\begin{array}{l}\text { Pilutti et al., } \\
2019 \text { [71] }\end{array}$ & $\begin{array}{l}\text { Randomized, } \\
\text { controlled trial, } \\
n=11\end{array}$ & $\begin{array}{l}\text { FES cycling exercise } \\
(n=6) \text { or passive leg } \\
\text { cycling }(n=5) \text { for } \\
24 \text { weeks }\end{array}$ & $\begin{array}{l}\text { FSS, MFIS, SF-PMQ, } \\
\text { MSIS-29 }\end{array}$ & $\begin{array}{l}\text { - Moderate to large } \\
\text { improvements in cognitive } \\
\text { processing speed }(\mathrm{d}=0.53), \\
\text { fatigue severity }(\mathrm{d}=-0.92), \\
\text { fatigue impact }(\mathrm{d}=-0.45 \\
\text { to }-0.68) \text { and pain } \\
\text { symptoms }(\mathrm{d}=-0.67)\end{array}$ \\
\hline
\end{tabular}

Although those studies are based on a small sample of participants, the findings support the concept that interventions modifying the sensorimotor network activity balances could be suitable non-pharmacological treatments for MS-related fatigue. The results of these studies on the effectiveness of NIBS are listed in Table 6. 
Table 6. Clinical studies of non-invasive brain stimulation in patients with MS-related fatigue.

\begin{tabular}{|c|c|c|c|c|}
\hline Study, Year & Study Design & $\begin{array}{c}\text { Type of } \\
\text { Intervention }\end{array}$ & $\begin{array}{l}\text { Outcome } \\
\text { Measures }\end{array}$ & Main Findings \\
\hline $\begin{array}{l}\text { Chalah et al., } \\
2020 \text { [73] }\end{array}$ & $\begin{array}{l}\text { randomized, } \\
\text { sham-controlled } \\
\text { study, } n=11\end{array}$ & bilateral tDCS & FSS, MFIS & $\begin{array}{l}\text { Active but not sham tDCS resulted in } \\
\text { a significant improvement of fatigue } \\
\text { at day } 5(p<0.05) \text {, an effect that seems } \\
\text { to last at least } 1 \text { week following the } \\
\text { stimulation }(p=0.05) \text {. }\end{array}$ \\
\hline $\begin{array}{l}\text { Cancelli et al., } \\
2018 \text { [74] }\end{array}$ & $\begin{array}{l}\text { randomized, } \\
\text { double-blind, } \\
\text { sham-controlled, } \\
\text { crossover study, } \\
n=10\end{array}$ & tDCS & MFIS & $\begin{array}{l}\text { - The amelioration of fatigue symptoms } \\
\text { after real stimulation ( } 40 \% \text { of baseline) } \\
\text { was significantly larger than after } \\
\text { sham stimulation }(14 \%, p=0.012) \text {. } \\
\text { Anodal whole-body } \mathrm{S} 1 \text { induced a } \\
\text { significant fatigue reduction in mildly } \\
\text { disabled MS patients when the } \\
\text { fatigue-related symptoms severely } \\
\text { hampered their quality of life. }\end{array}$ \\
\hline $\begin{array}{l}\text { Saiote et al., } \\
2014 \text { [76] }\end{array}$ & $\begin{array}{l}\text { sham-controlled, } \\
\text { double-blind } \\
\text { intervention } \\
\text { study }\end{array}$ & $\begin{array}{l}\text { excitability- } \\
\text { enhancing anodal } \\
\text { tDCS }\end{array}$ & $\begin{array}{l}\text { FSS, MSFSS, } \\
\text { MFIS }\end{array}$ & $\begin{array}{l}\text { In the whole group, the analysis } \\
\text { scores of the fatigue scales were not } \\
\text { altered by tDCS. } \\
\text { In an exploratory analysis, a } \\
\text { correlation between response to the } \\
\text { stimulation regarding subjectively } \\
\text { perceived fatigue and lesion load in } \\
\text { the left frontal cortex was tested. } \\
\text { Patients responding positively to } \\
\text { anodal tDCS had higher lesion load } \\
\text { compared to non-responding patients. }\end{array}$ \\
\hline
\end{tabular}
Abbreviations: tDCS: Transcranial Direct Current Stimulation; FSS: Fatigue Severity Scale; MFIS: Modified Fatigue
Impact Scale; MSFSS: Multiple Sclerosis Specific Fatigue Severity Scale.

Another interesting possibility is deep transcranial magnetic stimulation (rTMS). Gaede et al. reported on a positive influence of 18 consecutive deep brain H-coil repetitive rTMS sessions over 6 weeks. The authors drew attention to the significant median FSS decrease of 1.0 point (95\% CI ( 0.45 , 1.65)), which was sustained during follow-up [77].

Figure 1 illustrates the approach to the treatment of patients with MS-related fatigue, which is presented in this review (Figure 1). 


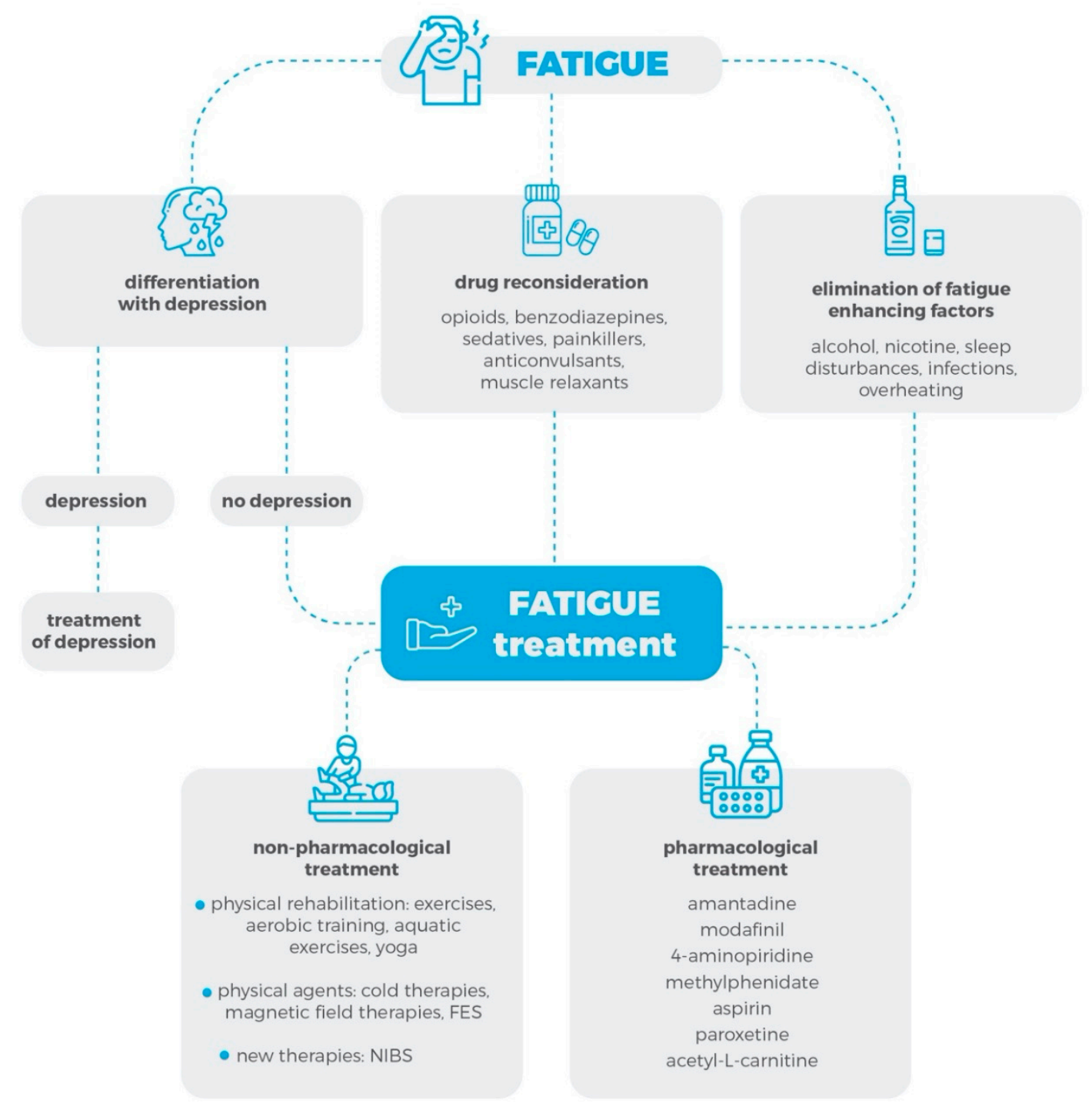

Figure 1. A protocol for the management of fatigue in MS patients, as presented in this review. Abbreviations: FES: Functional Electrical Stimulation; NIBS: Non-Invasive Brain Stimulation. This figure was designed using resources from Flaticon.com.

\section{Future Research and Directions}

Due to the fact that fatigue in MS patients is a complex clinical problem, future studies should look for not only precise diagnoses of depression and sleepiness, but also complex estimation of additional diseases that can influence fatigue. Currently, there are several techniques used to measure additional factors that can contribute to fatigue in MS. The most important are positron emission tomography (PET) and magnetic resonance imaging (MRI), brief repeatable battery of neuropsychological tests, and peripheral factors such as electromyography [78]. From our point of view, future research studies on MS-related fatigue should be more concentrated on psychological examination to distinguish fatigue from depression. It is very important to include in our thinking about fatigue the decreased physical and mental performance, which can lead to changes in psychological and peripheral factors. However, these changes depend not only on the kind of task that is performed and the environmental conditions, but also on the disease status [79]. 


\section{Conclusions}

When establishing a treatment plan for MS patients, particular attention should be paid to the thorough diagnosis of the fatigue syndrome, because its occurrence requires a different approach. This review presents a wide range of different therapeutic possibilities that might have a positive impact on MS-related fatigue. However, currently there is not a single versatile and fully effective treatment for this symptom. Therefore, a combination of pharmacological and non-pharmacological therapies, which were discussed in this review, is recommended. It is also worth considering trying new treatment possibilities, such as non-invasive brain stimulation. The aforementioned methods should not be omitted in the treatment plan, although more research should be done in the field of alternative treatment methods, as their use seems to be beneficial without causing significant side effects. Future research should have standardized research protocols and use the same scales in order to present more transparent and unambiguous results.

Author Contributions: Conceptualization, E.Z.-N., E.M.; methodology, E.M., L.W., J.K.; software, E.Z.-N., L.W.; formal analysis, E.M., J.K.; investigation, E.Z.-N., J.K., L.W., E.M.; resources, E.Z.-N., J.K., L.W., E.M; data curation, E.Z.-N.; writing-original draft preparation, E.Z.-N., J.K., L.W.; writing-review and editing, E.Z.-N., E.M.; visualization, E.Z.-N.; supervision, E.M.; project administration, E.M.; funding acquisition, E.M. All authors have read and agreed to the published version of the manuscript.

Funding: This study was supported by grant from the Medical University of Lodz no. 503/6-127-05/503-51-001-19.

Conflicts of Interest: The authors declare no conflict of interest.

\section{References}

1. Miller, E. Multiple Sclerosis. Adv. Exp. Med. Biol. 2012, 724, 222-238. [PubMed]

2. Pugliatti, M.; Rosati, G.; Carton, H.; Riise, T.; Drulovic, J.; Vecsei, L.; Milanov, I. The epidemiology of multiple sclerosis in Europe. Eur. J. Neurol. 2006, 13, 700-722. [CrossRef]

3. Chalah, M.A.; Riachi, N.; Ahdab, R.; Créange, A.; Lefaucheur, J.-P.; Ayache, S.S. Fatigue in Multiple Sclerosis: Neural Correlates and the Role of Non-Invasive Brain Stimulation. Front. Cell. Neurosci. 2015, 9, 460. [CrossRef]

4. Comi, L.; Leocani, L.; Rossi, P.; Colombo, B. Physiopathology and treatment of fatigue in multiple sclerosis. J. Neurol. 2001, 248, 174-179. [CrossRef] [PubMed]

5. Flensner, G.; Ek, A.-C.; Söderhamn, O.; Landtblom, A.-M. Sensitivity to heat in MS patients: A factor strongly influencing symptomology-An explorative survey. BMC Neurol. 2011, 11, 27. [CrossRef]

6. Krupp, L.B.; Christodoulou, C. Fatigue in multiple sclerosis. Curr. Neurol. Neurosci. Rep. 2001, 1, $294-298$. [CrossRef]

7. Mollaoğlu, M.; Üstün, E. Fatigue in multiple sclerosis patients. J. Clin. Nurs. 2009, 18, 1231-1238. [CrossRef]

8. Weiland, T.J.; Jelinek, G.A.; Marck, C.H.; Hadgkiss, E.J.; Van Der Meer, D.M.; Pereira, N.G.; Taylor, K.L. Clinically Significant Fatigue: Prevalence and Associated Factors in an International Sample of Adults with Multiple Sclerosis Recruited via the Internet. PLoS ONE 2015, 10, e0115541. [CrossRef] [PubMed]

9. Coates, K.D.; Aboodarda, S.J.; Krüger, R.L.; Martin, T.; Metz, L.M.; Jarvis, S.E.; Millet, G.Y. Multiple sclerosis-related fatigue: The role of impaired corticospinal responses and heightened exercise fatigability. J. Neurophysiol. 2020, 124, 1131-1143. [CrossRef]

10. Kratz, A.L.; Murphy, S.L.; Braley, T.J. Ecological Momentary Assessment of Pain, Fatigue, Depressive, and Cognitive Symptoms Reveals Significant Daily Variability in Multiple Sclerosis. Arch. Phys. Med. Rehabil. 2017, 98, 2142-2150. [CrossRef]

11. Giovannoni, G. Multiple sclerosis related fatigue. J. Neurol. Neurosurg. Psychiatry 2006, 77, 2-3. [CrossRef]

12. Hadjimichael, O.; Vollmer, T.; Oleen-Burkey, M. Fatigue characteristics in multiple sclerosis: The North American Research Committee on Multiple Sclerosis (NARCOMS) survey. Heal. Qual. Life Outcomes 2008, 6, 100. [CrossRef]

13. Khan, F.; Amatya, B.; Galea, M. Management of Fatigue in Persons with Multiple Sclerosis. Front. Neurol. 2014, 5, 177. [CrossRef]

14. Chen, M.H.; Wylie, G.R.; Sandroff, B.M.; Dacosta-Aguayo, R.; DeLuca, J.; Genova, H.M. Neural mechanisms underlying state mental fatigue in multiple sclerosis: A pilot study. J. Neurol. 2020, 267, 2372-2382. [CrossRef] 
15. Braley, T.J.; Chervin, R.D. Fatigue in Multiple Sclerosis: Mechanisms, Evaluation, and Treatment. Sleep 2010, 33, 1061-1067. [CrossRef]

16. Gumus, H. Fatigue Can Be Objectively Measured in Multiple Sclerosis. Arch. Neuropsychiatry 2018, 55, S76-S79. [CrossRef] [PubMed]

17. Téllez, N.; Río, J.; Tintoré, M.; Nos, C.; Galán, I.; Montalban, X. Does the Modified Fatigue Impact Scale offer a more comprehensive assessment of fatigue in MS? Mult. Scler. J. 2005, 11, 198-202. [CrossRef]

18. Gobbi, C.; A Rocca, M.; Riccitelli, G.; Pagani, E.; Messina, R.; Preziosa, P.; Colombo, B.; Rodegher, M.; Falini, A.; Comi, G.; et al. Influence of the topography of brain damage on depression and fatigue in patients with multiple sclerosis. Mult. Scler. J. 2013, 20, 192-201. [CrossRef]

19. Pardini, M.; Bonzano, L.; Bergamino, M.; Bommarito, G.; Feraco, P.; Murugavel, A.; Bove, M.; Brichetto, G.; Uccelli, A.; Mancardi, G.; et al. Cingulum bundle alterations underlie subjective fatigue in multiple sclerosis. Mult. Scler. J. 2014, 21, 442-447. [CrossRef]

20. Pellicano, C.; Gallo, A.; Li, X.; Ikonomidou, V.N.; Evangelou, I.E.; Ohayon, J.M.; Stern, S.K.; Ehrmantraut, M.; Cantor, F.; McFarland, H.F.; et al. Relationship of Cortical Atrophy to Fatigue in Patients with Multiple Sclerosis. Arch. Neurol. 2010, 67, 447-453. [CrossRef]

21. Kraft, G.H.; Bowen, J.; Rammohan, K.W.; Lynn, D.J.; Stankoff, B.; Waubant, E.; Lubetzki, C.; Clanet, M.; French Modafinil Study Group. Modafinil for fatigue in MS: A randomized placebo-controlled double-blind study. Neurology 2005, 65, 1995-1997. [CrossRef]

22. Jensen, H.B.; Ravnborg, M.; Dalgas, U.; Stenager, E. 4-Aminopyridine for symptomatic treatment of multiple sclerosis: A systematic review. Ther. Adv. Neurol. Disord. 2013, 7, 97-113. [CrossRef]

23. Rossini, P.M.; Pasqualetti, P.; Pozzilli, C.; Grasso, M.G.; Millefiorini, E.; Graceffa, A.; A Carlesimo, G.; Zibellini, G.; Caltagirone, C. Fatigue in progressive multiple sclerosis: Results of a randomized, double-blind, placebo-controlled, crossover trial of oral 4-aminopyridine. Mult. Scler. J. 2001, 7, 354-358. [CrossRef] [PubMed]

24. Generali, J.A.; Cada, D.J. Amantadine: Multiple Sclerosis-Related Fatigue. Hosp. Pharm. 2014, 49, 710-712. [CrossRef]

25. Ledinek, A.H.; Sajko, M.C.; Rot, U. Evaluating the effects of amantadin, modafinil and acetyl-1-carnitine on fatigue in multiple sclerosis-Result of a pilot randomized, blind study. Clin. Neurol. Neurosurg. 2013, 115, S86-S89. [CrossRef] [PubMed]

26. Möller, F.; Poettgen, J.; Broemel, F.; Neuhaus, A.; Daumer, M.; Heesen, C. HAGIL (Hamburg Vigil Study): A randomized placebo-controlled double-blind study with modafinil for treatment of fatigue in patients with multiple sclerosis. Mult. Scler. J. 2011, 17, 1002-1009. [CrossRef] [PubMed]

27. Stankoff, B.; Waubant, E.; Confavreux, C.; Edan, G.; Debouverie, M.; Rumbach, L.; Moreau, T.; Pelletier, J.; Lubetzki, C.; Clanet, M.G.; et al. Modafinil for fatigue in MS: A randomized placebo-controlled double-blind study. Neurology 2005, 64, 1139-1143. [CrossRef]

28. Lange, M.R.; Volkmer, M.; Heesen, C.; Liepert, J. Modafinil effects in multiple sclerosis patients with fatigue. J. Neurol. 2009, 256, 645-650. [CrossRef]

29. Tomassini, V.; Pozzilli, C.; Onesti, E.; Pasqualetti, P.; Marinelli, F.; Pisani, A.; Fieschi, C. Comparison of the effects of acetyl 1-carnitine and amantadine for the treatment of fatigue in multiple sclerosis: Results of a pilot, randomised, double-blind, crossover trial. J. Neurol. Sci. 2004, 218, 103-108. [CrossRef]

30. Ehde, D.M.; Kraft, G.H.; Chwastiak, L.; Sullivan, M.D.; Gibbons, L.E.; Bombardier, C.H.; Wadhwani, R. Efficacy of paroxetine in treating major depressive disorder in persons with multiple sclerosis. Gen. Hosp. Psychiatry 2008, 30, 40-48. [CrossRef]

31. Tsou, A.; Treadwell, J.; Erinoff, E.; Schoelles, K. Which treatments improve fatigue and quality of life in Multiple Sclerosis? Evidence appraisal and development of visual interactive evidence maps (P5.2-088). Neurology 2019, 92 (Suppl. 15), P5.2-088.

32. Yang, T.-T.; Wang, L.; Deng, X.-Y.; Yu, G. Pharmacological treatments for fatigue in patients with multiple sclerosis: A systematic review and meta-analysis. J. Neurol. Sci. 2017, 380, 256-261. [CrossRef]

33. Nourbakhsh, B.; Revirajan, N.; Waubant, E. Treatment of fatigue with methylphenidate, modafinil and amantadine in multiple sclerosis (TRIUMPHANT-MS): Study design for a pragmatic, randomized, double-blind, crossover clinical trial. Contemp. Clin. Trials 2018, 64, 67-76. [CrossRef] 
34. Triche, E.W.; Ruiz, J.A.; Olson, K.M.; Lo, A.C. Changes in Cognitive Processing Speed, Mood, and Fatigue in an Observational Study of Persons with Multiple Sclerosis Treated with Dalfampridine-ER. Clin. Neuropharmacol. 2016, 39, 73-80. [CrossRef]

35. Yadav, V.; Bever, C.; Bowen, J.; Bowling, A.; Weinstock-Guttman, B.; Cameron, M.; Bourdette, D.; Gronseth, G.S.; Narayanaswami, P. Summary of evidence-based guideline: Complementary and alternative medicine in multiple sclerosis: Report of the Guideline Development Subcommittee of the American Academy of Neurology. Neurology 2014, 82, 1083-1092. [CrossRef]

36. Niwald, M.; Redlicka, J.; Miller, E. The effects of aerobic training on the functional status, quality of life, the level of fatigue and disability in patients with multiple sclerosis-A preliminary report. Aktualności. Neurol. 2017, 17, 15-22. [CrossRef]

37. Asano, M.; Finlayson, M. Meta-Analysis of Three Different Types of Fatigue Management Interventions for People with Multiple Sclerosis: Exercise, Education, and Medication. Mult. Scler. Int. 2014, 2014, 798285. [CrossRef] [PubMed]

38. Stroud, N.M.; Minahan, C. The impact of regular physical activity on fatigue, depression and quality of life in persons with multiple sclerosis. Health Qual. Life Outcomes 2009, 7, 68. [CrossRef]

39. Heine, M.; Van De Port, I.; Rietberg, M.B.; Wegen, E.E.H.V.; Kwakkel, G. Exercise therapy for fatigue in multiple sclerosis. Cochrane Database Syst. Rev. 2015, CD009956. [CrossRef] [PubMed]

40. Langeskov-Christensen, M.; Bisson, E.J.; Finlayson, M.; Dalgas, U. Potential pathophysiological pathways that can explain the positive effects of exercise on fatigue in multiple sclerosis: A scoping review. J. Neurol. Sci. 2017, 373, 307-320. [CrossRef]

41. Kinnett-Hopkins, D.; Adamson, B.; Rougeau, K.; Motl, R.W. People with MS are less physically active than healthy controls but as active as those with other chronic diseases: An updated meta-analysis. Mult. Scler. Relat. Disord. 2017, 13, 38-43. [CrossRef] [PubMed]

42. Kalb, R.; Brown, T.R.; Coote, S.; Costello, K.; Dalgas, U.; Garmon, E.; Giesser, B.; Halper, J.; Karpatkin, H.; Keller, J.; et al. Exercise and lifestyle physical activity recommendations for people with multiple sclerosis throughout the disease course. Mult. Scler. J. 2020, 26, 1459-1469. [CrossRef]

43. Kierkegaard, M.; E Lundberg, I.; Olsson, T.; Johansson, S.; Ygberg, S.; Opava, C.H.; Holmqvist, L.W.; Piehl, F. High-intensity resistance training in multiple sclerosis-An exploratory study of effects on immune markers in blood and cerebrospinal fluid, and on mood, fatigue, health-related quality of life, muscle strength, walking and cognition. J. Neurol. Sci. 2016, 362, 251-257. [CrossRef]

44. Campbell, E.; Coulter, E.H.; Paul, L. High intensity interval training for people with multiple sclerosis: A systematic review. Mult. Scler. Relat. Disord. 2018, 24, 55-63. [CrossRef]

45. Dehkordi, A.H. Influence of yoga and aerobics exercise on fatigue, pain and psychosocial status in patients with multiple sclerosis: A Randomized Trial. J. Sports Med. Phys. Fit. 2015, 56, 1417-1422.

46. Mokhtarzade, M.; Ranjbar, R.; Majdinasab, N.; Patel, D.; Malanouri, S.M. Effect of aerobic interval training on serum IL-10, TNF $\alpha$, and adipokines levels in women with multiple sclerosis: Possible relations with fatigue and quality of life. Endocrine 2017, 57, 262-271. [CrossRef]

47. Mostert, S.; Kesselring, J. Effects of a short-term exercise training program on aerobic fitness, fatigue, health perception and activity level of subjects with multiple sclerosis. Mult. Scler. J. 2002, 8, 161-168. [CrossRef]

48. Devasahayam, A.J.; Chaves, A.R.; Lasisi, W.O.; Curtis, M.E.; Wadden, K.P.; Kelly, L.P.; Pretty, R.; Chen, A.; Wallack, E.M.; Newell, C.J.; et al. Vigorous cool room treadmill training to improve walking ability in people with multiple sclerosis who use ambulatory assistive devices: A feasibility study. BMC Neurol. 2020, 20, 1-18. [CrossRef]

49. Kargarfard, M.; Shariat, A.; Ingle, L.; Cleland, J.A.; Kargarfard, M. Randomized Controlled Trial to Examine the Impact of Aquatic Exercise Training on Functional Capacity, Balance, and Perceptions of Fatigue in Female Patients with Multiple Sclerosis. Arch. Phys. Med. Rehabil. 2018, 99, 234-241. [CrossRef] [PubMed]

50. Kooshiar, H.; Moshtagh, M.; A Sardar, M.; Foroughipour, M.; Shakeri, M.T.; Vahdatinia, B. Fatigue and quality of life of women with multiple sclerosis: A randomized controlled clinical trial. J. Sports Med. Phys. Fit. 2014, $55,668-674$.

51. Razazian, N.; Yavari, Z.; Farnia, V.; Azizi, A.; Kordavani, L.; Bahmani, D.S.; Holsboer-Trachsler, E.; Brand, S. Exercising Impacts on Fatigue, Depression, and Paresthesia in Female Patients with Multiple Sclerosis. Med. Sci. Sports Exerc. 2016, 48, 796-803. [CrossRef] 
52. Garrett, M.; Hogan, N.; Larkin, A.; Saunders, J.; Amigo-Benavent, M.; Coote, S. Exercise in the community for people with minimal gait impairment due to MS: An assessor-blind randomized controlled trial. Mult. Scler. J. 2012, 19, 782-789. [CrossRef]

53. Van Geel, F.; Van Asch, P.; Veldkamp, R.; Feys, P. Effects of a 10-week multimodal dance and art intervention program leading to a public performance in persons with multiple sclerosis - A controlled pilot-trial. Mult. Scler. Relat. Disord. 2020, 44, 102256. [CrossRef]

54. Garg, H.; Bush, S.; Gappmaier, E. Associations Between Fatigue and Disability, Functional Mobility, Depression, and Quality of Life in People with Multiple Sclerosis. Int. J. MS Care 2016, 18, 71-77. [CrossRef] [PubMed]

55. Armutlu, K.; Karabudak, R.; Nurlu, G. Physiotherapy approaches in the treatment of ataxic multiple sclerosis: A pilot study. Neurorehabil. Neural Repair 2001, 15, 203-211. [CrossRef]

56. Tarakci, E.; Yeldan, I.; E Huseyinsinoglu, B.; Zenginler, Y.; Eraksoy, M. Group exercise training for balance, functional status, spasticity, fatigue and quality of life in multiple sclerosis: A randomized controlled trial. Clin. Rehabil. 2013, 27, 813-822. [CrossRef]

57. Sangelaji, B.; Nabavi, S.M.; Estebsari, F.; Baneshi, M.M.; Rashidian, H.; Jamshidi, E.; Dastoorpoor, M. Effect of Combination Exercise Therapy on Walking Distance, Postural Balance, Fatigue and Quality of Life in Multiple Sclerosis Patients: A Clinical Trial Study. Iran. Red Crescent Med. J. 2014, 16, e17173. [CrossRef] [PubMed]

58. Mccullagh, R.; Fitzgerald, A.P.; Murphy, R.P.; Cooke, G. Long-term benefits of exercising on quality of life and fatigue in multiple sclerosis patients with mild disability: A pilot study. Clin. Rehabil. 2007, 22, $206-214$. [CrossRef]

59. Feys, P.; Helsen, W.; Liu, X.; Mooren, D.; Albrecht, H.; Nuttin, B.; Ketelaer, P. Effects of peripheral cooling on intention tremor in multiple sclerosis. J. Neurol. Neurosurg. Psychiatry 2005, 76, 373-379. [CrossRef]

60. Miller, E.; Mrowicka, M.; Malinowska, K.; Mrowicki, J.; Saluk-Juszczak, J.; Kędziora, J. Effects of whole-body cryotherapy on a total antioxidative status and activities of antioxidative enzymes in blood of depressive multiple sclerosis patients. World J. Biol. Psychiatry 2010, 12, 223-227. [CrossRef]

61. Miller, E.; Kostka, J.; Włodarczyk, T.; Dugué, B. Whole-body cryostimulation (cryotherapy) provides benefits for fatigue and functional status in multiple sclerosis patients. A case-control study. Acta Neurol. Scand. 2016, 134, 420-426. [CrossRef]

62. Gonzales, B.; Chopard, G.; Charry, B.; Berger, E.; Tripard, J.; Magnin, E.; Groslambert, A. Effects of a Training Program Involving Body Cooling on Physical and Cognitive Capacities and Quality of Life in Multiple Sclerosis Patients: A Pilot Study. Eur. Neurol. 2017, 78, 71-77. [CrossRef]

63. Tuncay, F. Özkan; Mollaoğlu, M. Effect of the cooling suit method applied to individuals with multiple sclerosis on fatigue and activities of daily living. J. Clin. Nurs. 2017, 26, 4527-4536. [CrossRef]

64. Nilsagård, Y.; Denison, E.; Gunnarsson, L.-G. Evaluation of a single session with cooling garment for persons with multiple sclerosis-A randomized trial. Disabil. Rehabil. Assist. Technol. 2006, 1, 225-233. [CrossRef]

65. Lappin, M.S.; Lawrie, F.W.; Richards, T.L.; Kramer, E.D. Effects of a pulsed electromagnetic therapy on multiple sclerosis fatigue and quality of life: A double-blind, placebo controlled trial. Altern. Ther. Health Med. 2003, 9, 38-48.

66. Piatkowski, J.; Kern, S.; Ziemssen, T. Effect of BEMER Magnetic Field Therapy on the Level of Fatigue in Patients with Multiple Sclerosis: A Randomized, Double-Blind Controlled Trial. J. Altern. Complement. Med. 2009, 15, 507-511. [CrossRef]

67. De Carvalho, M.L.L.; Motta, R.; Konrad, G.; Battaglia, M.A.; Brichetto, G. A randomized placebo-controlled cross-over study using a low frequency magnetic field in the treatment of fatigue in multiple sclerosis. Mult. Scler. J. 2011, 18, 82-89. [CrossRef] [PubMed]

68. Mostert, S.; Kesselring, J. Effect of pulsed magnetic field therapy on the level of fatigue in patients with multiple sclerosis-A randomized controlled trial. Mult. Scler. J. 2005, 11, 302-305. [CrossRef]

69. Barr, C.J.; Patritti, B.L.; Bowes, R.; Crotty, M.; McLoughlin, J.V. Orthotic and therapeutic effect of functional electrical stimulation on fatigue induced gait patterns in people with multiple sclerosis. Disabil. Rehabil. Assist. Technol. 2016, 12, 1-13. [CrossRef]

70. Chang, Y.-J.; Hsu, M.-J.; Chen, S.-M.; Lin, C.-H.; Wong, A.M.K. Decreased central fatigue in multiple sclerosis patients after 8 weeks of surface functional electrical stimulation. J. Rehabil. Res. Dev. 2011, 48, 555-564. [CrossRef] 
71. Pilutti, L.A.; Edwards, T.A.; Motl, R.W.; Sebastião, E. Functional Electrical Stimulation Cycling Exercise in People with Multiple Sclerosis: Secondary Effects on Cognition, Symptoms, and Quality of Life. Int. J. MS Care 2019, 21, 258-264. [CrossRef] [PubMed]

72. Liu, M.; Fan, S.; Xu, Y.; Cui, L. Non-invasive brain stimulation for fatigue in multiple sclerosis patients: A systematic review and meta-analysis. Mult. Scler. Relat. Disord. 2019, 36, 101375. [CrossRef]

73. Chalah, M.A.; Grigorescu, C.; Padberg, F.; Kümpfel, T.; Palm, U.; Ayache, S.S. Bifrontal transcranial direct current stimulation modulates fatigue in multiple sclerosis: A randomized sham-controlled study. J. Neural Transm. 2020, 127, 953-961. [CrossRef]

74. Cancelli, A.; Cottone, C.; Giordani, A.; Migliore, S.; Lupoi, D.; Porcaro, C.; Mirabella, M.; Rossini, P.M.; Filippi, M.M.; Tecchio, F. Personalized, bilateral whole-body somatosensory cortex stimulation to relieve fatigue in multiple sclerosis. Mult. Scler. J. 2017, 24, 1366-1374. [CrossRef]

75. Tecchio, F.; Cancelli, A.; Cottone, C.; Zito, G.; Pasqualetti, P.; Ghazaryan, A.; Rossini, P.M.; Filippi, M.M. Multiple sclerosis fatigue relief by bilateral somatosensory cortex neuromodulation. J. Neurol. 2014, 261, 1552-1558. [CrossRef]

76. Saiote, C.; Goldschmidt, T.; Timäus, C.; Steenwijk, M.D.; Opitz, A.; Antal, A.; Paulus, W.; Nitsche, M.A. Impact of transcranial direct current stimulation on fatigue in multiple sclerosis. Restor. Neurol. Neurosci. 2014, 32, 423-436. [CrossRef]

77. Gaede, G.; Tiede, M.; Lorenz, I.; Brandt, A.U.; Pfueller, C.; Dörr, J.; Bellmann-Strobl, J.; Piper, S.K.; Roth, Y.; Zangen, A.; et al. Safety and preliminary efficacy of deep transcranial magnetic stimulation in MS-related fatigue. Neurol. Neuroimmunol. Neuroinflamm. 2017, 5, e423. [CrossRef]

78. Noakes, T.D.; Gibson, A.S.C.; Lambert, E.V. From catastrophe to complexity: A novel model of integrative central neural regulation of effort and fatigue during exercise in humans. Br. J. Sports Med. 2004, 38, 511-514. [CrossRef]

79. Rudroff, T.; Kindred, J.H.; Ketelhut, N.B. Fatigue in Multiple Sclerosis: Misconceptions and Future Research Directions. Front. Neurol. 2016, 7, 122. [CrossRef] [PubMed]

Publisher's Note: MDPI stays neutral with regard to jurisdictional claims in published maps and institutional affiliations.

(C) 2020 by the authors. Licensee MDPI, Basel, Switzerland. This article is an open access article distributed under the terms and conditions of the Creative Commons Attribution (CC BY) license (http://creativecommons.org/licenses/by/4.0/). 